Thorning, L., Bower, M., Hardwick, C. D. \& Hood, P. J. 1985: Greenland ice cap aeromagnetic survey 1984: reconnaissance lines in southern Greenland. Rapp. Grønlands geol. Unders. 125, 83-84.

C. D. H.,

Flight Research Laboratory, National Research Council, Montreal Road, Ottawa, Ontario, Canada, K1A 0R6.
M. B.,

Flight Research Section, Bldg. U-61, National Research Council, Montreal Road, Ottawa, Ontario, Canada, K1A 0R6.
P. J. H.,

Regional Geophysics Subdivision, Resource Geophys. \& Geochem. Div., Geological Survey of Canada, 601 Booth Street, Ottawa, Ontario, Canada, K1A 0E8.

\title{
Reconnaissance dating of Archaean rocks from South-East Greenland
}

\author{
J. C. Escher, F. Kalsbeek, O. Larsen, T. F. D. Nielsen and P. N. Taylor
}

A major project of geological investigations in South-East Greenland is planned for 1986 and 1987 with the aim of producing sheet 14 of the 1:500 000 geological map series covering Greenland. The northern part of the map sheet is occupied by the Nagssugtoqidian mobile belt, and the southern part consists mainly of Archaean rocks. Because of difficulties of access, the Archaean part of the area is poorly known. Geological reconnaissance has been carried out by Bridgwater \& Gormsen (1969), and, as a preparation for the 1986 and 1987 expeditions, by Escher \& Nielsen $(1982,1983)$ and Nielsen \& Escher (1985). This report presents reconnaissance $\mathrm{Rb}-\mathrm{Sr}$ and $\mathrm{Pb}-\mathrm{Pb}$ whole-rock age determinations from the Archaean part of the map sheet.

\section{General geology}

The following summary (see Nielsen \& Escher, 1985; and papers quoted therein) is exclusively based on short reconnaissance visits and a single survey from the air, and may have to be reconsidered after more detailed mapping. The Archaean terrain (fig. 1) is composed of a granulite facies core region of brownish agmatitic hypersthene-bearing gneisses and brownish migmatitic agmatites with meta-igneous inclusions ranging from ultramafic to dioritic. The core region is surrounded to the north, west and south by grey agmatitic amphibolite facies gneisses with, often large, mafic inclusions and with several major isoclinally folded supracrustal units, dominated by amphibolites. These two major metamorphic complexes are commonly separated by intrusive rocks: charnockites, gabbros, and rocks of dioritic to granitic composition. Where the boundary between the high-grade core and the grey gneisses is not obscured by intrusions, a prograde metamorphic transition is found.

$\mathrm{A}$ few $\mathrm{K}$-Ar and ${ }^{40} \mathrm{Ar}-{ }^{39} \mathrm{Ar}$ ages (on whole-rock samples, hornblende and biotite) have been reported from the area, and range from c. 2700 - c. 2200 Ma (Larsen, 1969; Bridgwater, 1970, 1971). A single U-Pb 'diffusion' age of $2808 \mathrm{Ma}$ has been obtained for zircons from supracrustal rocks near Tingmiarmiut (quoted in Pedersen et al., 1974) and presumably 


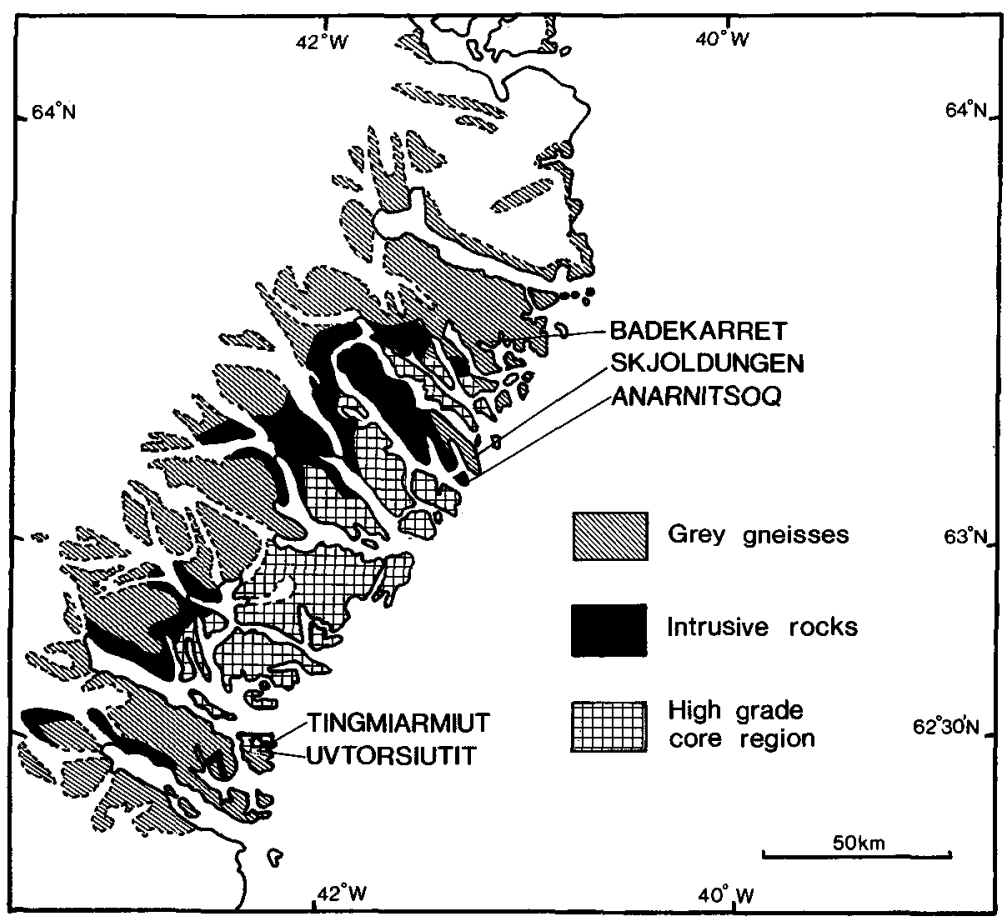

Fig. 1. Geological sketch map of the Archaean terrain of South-East Greenland from Nielsen \& Escher (1985), with the localities mentioned in the text.

dates a phase of high-grade metamorphism. The same authors have obtained a Rb-Sr wholerock isochron age of $2565 \pm 75 \mathrm{Ma}$ for acid volcanic rocks and associated gneisses from the southern border zone of the Archaean terrain of South-East Greenland.

\section{Sampling}

The following material was used for age determination:

Samples 288561/1-13. Gneisses from the border zone between the high-grade core region and the grey gneisses were collected on the island of Uvtorsiutit on which the weather station Tingmiarmiut is situated. It is not certain whether these rocks have been affected by granulite facies metamorphism. Samples 288562/1-4 represent mafic inclusions in these gneisses, which, according to the field evidence, may be among the oldest rocks in SE Greenland.

Samples 288138-288142. These are mafic inclusions in the grey gneisses near Badekarret ('the bathtub'), a mountain north of Skjoldungen. They are large inclusions which may be the remnants of mafic intrusive sheets.

Samples 288544/1-20. These represent granite sheets which cut late intrusive charnockitic rocks on the island of Anarnitsoq near Skjoldungen. These granites are weakly foliated and belong to the youngest intrusive rocks in the area. 


\section{Results}

The 'old' gneisses and their inclusions from Uvtorsiutit have low $\mathrm{Rb} / \mathrm{Sr}$ ratios and are therefore not particularly well suited for $\mathrm{Rb}$-Sr age determinations. Six samples of the gneisses and two inclusions were selected for analysis. The inclusions from Badekarret also have low $\mathrm{Rb} / \mathrm{Sr}$ ratios - two samples were analysed. The granite sheets from Anarnitsoq have a favourable range of $\mathrm{Rb} / \mathrm{Sr}$ ratios and ten samples were selected for analysis. $\mathrm{Rb} / \mathrm{Sr} \mathrm{ra}-$ tios and Sr-isotopic compositions were determined at the Institute of Petrology, University of Copenhagen, and $\mathrm{Pb}$-isotopic compositions at the Age and Isotope Laboratory, University of Oxford. The analytical data are given in Table 1 and are shown graphically in figs 2 and 3.

The Rb-Sr data for the granite sheets of Anarnitsoq yield an age of $2640 \pm 80 \mathrm{Ma}$, initial ${ }^{87} \mathrm{Sr} /{ }^{86} \mathrm{Sr}\left(\mathrm{Sr}_{i}\right)$ ratio $0.7028 \pm 0.0012$ and an MSWD (mean square of weighted deviates) of 12.6. If the most aberrant sample (288544/3) is omitted from the isochron calculation the remaining 9 samples yield an age of $2670 \pm 65 \mathrm{Ma}, \mathrm{Sr}_{\mathrm{i}} 0.7021 \pm 0.0011$ and MSWD 5.4 (all errors at the $95 \%$ level of confidence; $\lambda^{87} \mathrm{Rb}=1.42 \times 10^{-11} \mathrm{a}^{-1}$ ). Despite the imperfect fit of the data points to the isochron, reflected by the high MSWD values, the age is relatively well defined because of the favourable range in $\mathrm{Rb} / \mathrm{Sr}$ ratios of the samples. The $\mathrm{Pb}$-isotope data

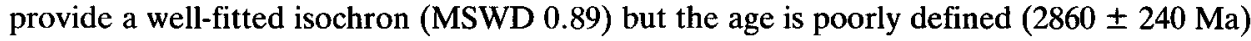
because of the limited range in the $\mathrm{Pb}$-isotopic compositions of the samples. The $\mu_{1}$ value (the first-stage ${ }^{238} \mathrm{U} /{ }^{204} \mathrm{~Pb}$ ratio) associated with this isochron is $7.47 \pm 0.25$. The combined evidence of the $\mathrm{Rb}-\mathrm{Sr}$ and $\mathrm{Pb}-\mathrm{Pb}$ data suggests an age of c. $2700 \mathrm{Ma}$ for these granites.

Table 1. Isotopic data for the Archaean rocks from South-East Greenland

\begin{tabular}{|c|c|c|c|c|c|c|c|}
\hline Sample No & $\mathbf{R b}$ & $\mathrm{Sr}$ & ${ }^{87} \mathrm{Rb} /{ }^{86} \mathrm{Sr}$ & ${ }^{87} \mathrm{Sr} /{ }^{86} \mathrm{Sr}$ & ${ }^{206} \mathrm{~Pb} /{ }^{204} \mathrm{~Pb}$ & ${ }^{07} \mathrm{~Pb} /{ }^{204} \mathrm{~Pb}$ & ${ }^{208} \mathrm{~Pb} /{ }^{204} \mathrm{~Pb}$ \\
\hline 288561-1 & 46 & 528 & 0.252 & 0.7124 & 13.087 & 14.234 & 32.825 \\
\hline 4 & 51 & 473 & 0.310 & 0.7155 & 13.735 & 14.382 & 34.097 \\
\hline 5 & 69 & 590 & 0.340 & 0.7152 & 13.391 & 14.495 & 34.374 \\
\hline 6 & $i 77$ & 403 & 0.551 & 0.7255 & 13.405 & 14.307 & 35.137 \\
\hline 7 & 45 & 670 & 0.194 & 0.7112 & 13.279 & 14.278 & 33.230 \\
\hline 8 & 40 & 527 & 0.222 & 0.7128 & 12.987 & 14.204 & 33.491 \\
\hline $288562-1$ & 104 & 882 & 0.342 & 0.7145 & 13.215 & 14.307 & 33.548 \\
\hline 2 & 48 & 1540 & 0.090 & 0.7054 & 13.321 & 14.360 & 34.634 \\
\hline 288140 & 23 & 826 & 0.080 & 0.7050 & 15.127 & 14.691 & 35.368 \\
\hline 288142 & 35 & 344 & 0.296 & 0.7127 & 14.589 & 14.545 & 34.710 \\
\hline 288544-1 & 188 & 290 & 1.888 & 0.7748 & 14.249 & 14.521 & 35.617 \\
\hline 2 & 120 & 373 & 0.935 & 0.7373 & 13.415 & 14.345 & 33.249 \\
\hline 3 & 53 & 373 & 0.412 & 0.7202 & 13.868 & 14.469 & 33.559 \\
\hline 4 & 158 & 325 & 1.415 & 0.7573 & 13.524 & 14.382 & 33.272 \\
\hline 5 & 168 & 302 & 1.608 & 0.7647 & 13.601 & 14.411 & 34.221 \\
\hline 6 & 147 & 250 & 1.712 & 0.7682 & 13.513 & 14.381 & 35.439 \\
\hline 10 & 124 & 314 & 1.143 & 0.7477 & 13.775 & 14.452 & 35.404 \\
\hline 12 & 74 & 789 & 0.270 & 0.7131 & 13.489 & 14.365 & 33.054 \\
\hline 14 & 100 & 475 & 0.607 & 0.7249 & 13.469 & 14.367 & 33.249 \\
\hline 17 & 77 & 711 & 0.315 & 0.7144 & 13.277 & 14.333 & 33.032 \\
\hline
\end{tabular}

Precisions: $\mathrm{Rb}$ and $\mathrm{Sr}$ concentrations (in ppm) are estimates only, \pm c. $5 \% ;{ }^{87} \mathrm{Sr} /{ }^{86} \mathrm{Sr}$ (normalised and relative to the Eimer and Amend standard $=0.7080) \pm c .0 .0002 ;{ }^{87} \mathrm{Rb} /{ }^{86} \mathrm{Sr}$ ratios $(\mathrm{XRF}$ and calibrated against USGS standard rocks) $\pm c$. $1 \%$; Pb-isotopic ratios (corrected for mass fractionation) $\pm c .0 .1 \%$. All precisions quoted at the $1 \sigma$ level. 

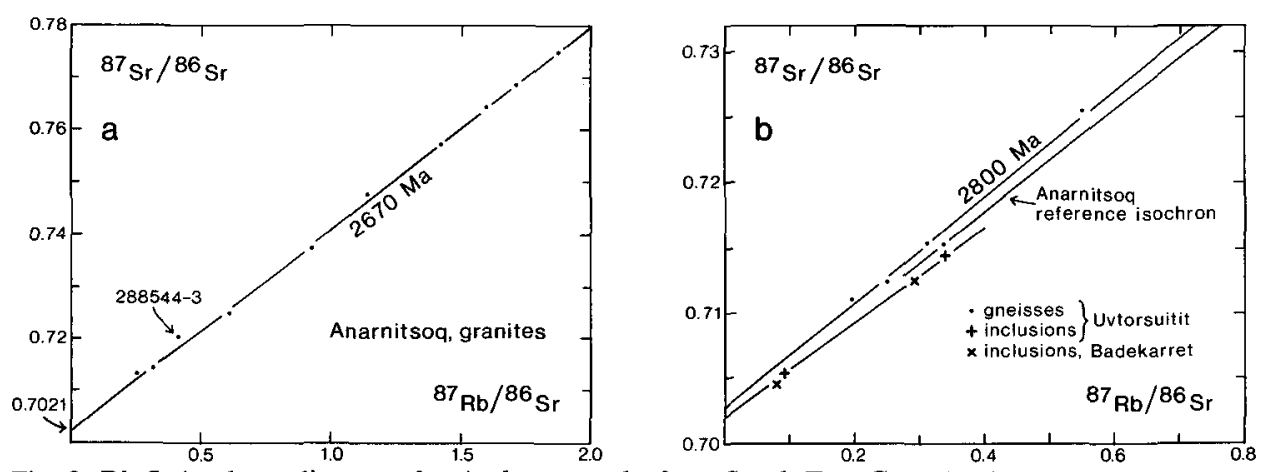

Fig. 2. Rb-Sr isochron diagrams for Archaean rocks from South-East Greenland.

The old gneisses from Uvtorsiutit scatter about a reference isochron of $c .2800 \mathrm{Ma}$ in the $\mathrm{Rb}$-Sr isochron diagram (fig. $2 \mathrm{~b}$ ). The wide scatter of the data points about this line (MSWD 19.0 ) coupled with the limited range in $\mathrm{Rb} / \mathrm{Sr}$ ratios results in a very poor definition of the age and $\mathrm{Sr}_{\mathrm{i}}$ values $(2720 \pm 500 \mathrm{Ma} ; 0.7031 \pm 0.0025)$. Nevertheless the data points fall above the isochron line for the late granites of Anarnitsoq, consistent with an older age for these gneisses. A very limited range was also obtained for the Pb-isotope data. Five of the six samples fall below the Anarnitsoq reference isochron (fig. $3 \mathrm{~b}$ ) and define an isochron: age 3080 $\pm 300 \mathrm{Ma}, \mu_{1} 7.55 \pm 0.41$, MSWD 0.05. For unknown reasons the sixth sample (288561/5) lies far above this isochron. Consideration of the $\mathrm{Rb}-\mathrm{Sr}$ and $\mathrm{Pb}-\mathrm{Pb}$ data indicates that these rocks are at least c. $2800 \mathrm{Ma}$, but not more than $c .3300 \mathrm{Ma}$ old.

Both sets of inclusions consist of a low $\mathrm{Rb} / \mathrm{Sr}$ and a slightly higher $\mathrm{Rb} / \mathrm{Sr}$ sample. The two sets fall on a common $\mathrm{Rb}-\mathrm{Sr}$ isochron which yields an age of $2490 \pm 130 \mathrm{Ma}, \mathrm{Sr}_{\mathrm{i}} 0.7020 \pm$ 0.0004 , and MSWD 0.1. The higher $\mathrm{Rb} / \mathrm{Sr}$ samples lie well below the isochron defined by the late granite sheets. This suggests that the inclusions did not become closed $\mathrm{Rb}-\mathrm{Sr}$ systems before c. $2500 \mathrm{Ma}$. The $\mathrm{Pb}$-isotopic compositions for three of the four inclusions fall near the isochron defined by the late granite samples. The fourth sample (288142) falls far below this isochron.
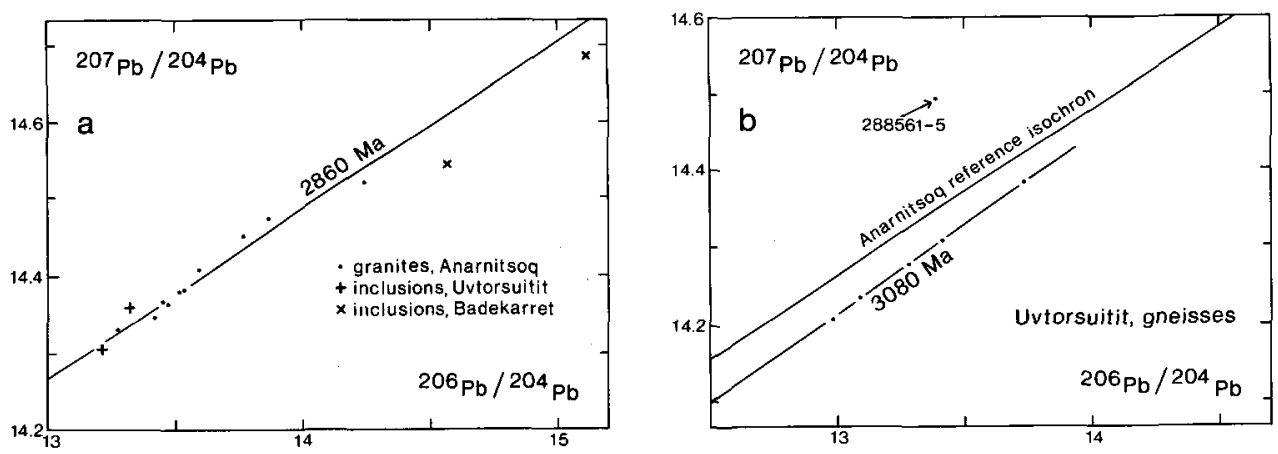

Fig. 3. $\mathrm{Pb}-\mathrm{Pb}$ isochron diagrams for Archaean rocks from South-East Greenland. 


\section{Discussion}

One of the important questions to be addressed during the 1986-1987 programme is whether the Archaean rocks of South-East Greenland contain components of early Archaean crust comparable to the $3600 \mathrm{Ma}$ Amîtsoq gneisses from the Godthåbsfjord region of West Greenland. During the reconnaissance mapping the possibility was considered that the high-grade core region might consist of such early Archaean rocks. The preliminary isotope data reported here do not confirm this. The ages obtained, though not precise, are comparable to those found for the late Archaean gneisses of West Greenland (3000-2600 Ma: Moorbath \& Pankhurst, 1976; Kalsbeek \& Pidgeon, 1980). The relatively low $\mathrm{Sr}_{\mathrm{i}}$ values make it unlikely that the investigated rocks have had a prolonged crustal history before c. $2800 \mathrm{Ma}$. The $\mathrm{Pb}$-isotope data confirm this. Late Archaean rocks in West Greenland that have a significant component of lead derived from early Archaean rocks consistently have model $\mu_{1}$ values much lower than $c .7 .5$ (Taylor et al., 1980). Although the investigated samples most probably do not have an early Archaean origin, this obviously does not prove the absence of early Archaean rocks elsewhere in South-East Greenland.

A detailed interpretation of the ages obtained is not straightforward. This is most clearly demonstrated by the young apparent age obtained for the mafic inclusions: the inclusions from Uvtorsiutit at least must belong to the oldest rocks studied here. Apparently, these rocks were not closed for diffusion of $\mathrm{Rb}$ and $\mathrm{Sr}$ before $c .2500 \mathrm{Ma}$. The isotope data together with the field evidence suggest an extended period of igneous and metamorphic activity comparable to that of the Godthåbsfjord and Fiskenæsset areas of West Greenland. Kalsbeek \& Pidgeon (1980) have shown that in such cases Rb-Sr whole-rock ages may no longer date specific intrusive or metamorphic events, but fall somewhere within the time interval between the intrusion of the rocks and the final closure of the isotope systems. This may also be the case for the rocks studied here, and the excessive scatter of the isotope data about the isochrons would be consistent with this interpretation.

Acknowledgements. The laboratories for isotope geology and X-ray fluorescence spectrometry at the Institute of Petrology, University of Copenhagen, are supported by the Natural Science Research Council (SNF). The Age and Isotope Laboratory at the Department of Earth Sciences, University of Oxford, is funded by a grant from the Natural Environment Research Council to Dr. S. Moorbath. We thank the staff of these laboratories for advice and skilled technical assistance with the analyses.

\section{References}

Bridgwater, D. 1970: A compilation of $\mathrm{K} / \mathrm{Ar}$ age determinations on rocks from Greenland carried out in 1969. Rapp. Grønlands geol Unders. 28, 47-55.

Bridgwater, D. 1971: Routine K/Ar age determinations on rocks from Greenland carried out for GGU in 1970. Rapp. Grønlands geol. Unders. 35, 52-60.

Bridgwater, D. \& Gormsen, K. 1969: Geological reconnaissance of the Precambrian rocks of SouthEast Greenland. Rapp. Grønlands geol. Unders. 19, 43-50.

Escher, J. C. \& Nielsen, T. F. D. 1982: Reconnaissance mapping of the Precambrian rocks between Uivaq $\left(63^{\circ} 03^{\prime} \mathrm{N}\right)$ and Bernstorffs Isfjord $\left(63^{\circ} 38^{\prime} \mathrm{N}\right)$, South-East Greenland. Rapp. Grønlands geol. Unders. 110, 77-80.

Escher, J. C. \& Nielsen, T. F. D. 1983: Archaean gneisses and supracrustal rocks of the Tingmiarmiut region, South-East Greenland. Rapp. Grønlands geol. Unders. 115, 79-82. 
Kalsbeek, F. \& Pidgeon, R. T. 1980: The geological significance of Rb-Sr whole-rock isochrons of polymetamorphic Archaean gneisses, Fiskenæsset area, southern West Greenland. Earth planet. Sci. Lett. 50, 225-237.

Larsen, O. 1969: K/Ar age determinations. Rapp. Grønlands geol. Unders. 19, 62-67.

Moorbath, S. \& Pankhurst, R. J. 1976: Further rubidium-strontium age and isotope evidence for the nature of the late Archaean plutonic event in West Greenland. Nature 262, 62-67.

Nielsen, T. F. D. \& Escher, J. C. 1985: Preparation for the South-East Greenland mapping project 1986-1987. Rapp. Grønlands geol. Unders. 125, 84-87.

Pedersen, S., Larsen, O., Bridgwater, D. \& Watterson, J. 1974: Rb/Sr whole-rock isochron age determinations on metamorphosed acid volcanic rocks and granitic gneisses from the Ketilidian mobile belt, South-East Greenland. Rapp. Grønlands geol. Unders. 66, 12-20.

Taylor, P. N., Moorbath, S., Goodwin, R. \& Petrykowski, A. C. 1980: Crustal contamination as an indicator of the extent of early Archaean crust: $\mathrm{Pb}$ isotopic evidence from the late Archaean gneisses of West Greenland. Geochim. cosmochim. Acta 44, 1437-1453.

O. L.,

Institut for Petrologi,

Københavns Universitet,

Øster Voldgade 10 ,

DK-1350 Copenhagen $\mathrm{K}$,

Denmark.
P. N. T.,

Department of Earth Sciences, University of Oxford, Oxford OX1 3PR,

U.K.

\section{Oil geological studies in central East Greenland}

\section{S. Piasecki and C. Marcussen}

Field work undertaken in central East Greenland during August 1985 was a follow-up of the oil geological studies by GGU expeditions to Jameson Land in 1982 and 1983 (Surlyk, 1983; Surlyk et al., 1984a). Three major subjects were covered by the field work.

The Permian-Triassic boundary was studied along the western margin of the Jameson Land basin (Surlyk et al., 1984b). A series of closely sampled sections along the exposures of the eastern part of the Schuchert Dal was completed. The sampled material will be analysed with respect to source rock quality, maturity and stratigraphy.

Secondly, the analysis of the regional maturity in southern Jameson Land based on the material from the 1982-83 expeditions indicates a specific surface maturation pattern (Piasecki, 1985; Thomsen, 1985) which had to be confirmed or rejected by analyses of further material from localities throughout the area. New material was collected along Hurry Inlet and in the southern and western parts of Jameson Land. Maturity studies will be supplemented by stratigraphical and geochemical analyses at these localities.

The third target of the field work was to start oil geological studies of the area north of Kong Oscar Fjord, and to locate drill sites for shallow-core drilling in immature potential source rocks. The island of Traill $\emptyset$ was visited for two days of helicopter reconnaissance. Wollaston Forland was visited for two days at the end of the season in co-operation with geologists of a British Petroleum (BP) party working in this area. Material was collected for preliminary source rock studies and biostratigraphy. 